\title{
Maternal-child blood group incompatibility and other perinatal events increase the risk for early-onset Type 1 (insulin-dependent) diabetes mellitus
}

\author{
G.Dahlquist ${ }^{1}$ and B. Källén ${ }^{2}$ \\ ${ }^{1}$ Department of Pediatrics and Department of Epidemiology and Health Care Research, University of Umeå, Umeå, \\ ${ }^{2}$ Department of Embryology, University of Lund, Lund, Sweden
}

Summary. The nationwide Swedish Childhood Diabetes Registry, which ascertains $99 \%$ of recent-onset Type 1 (insulin-dependent) diabetic children (0-14 years) in Sweden, was linked with the Swedish Medical Birth Registry. A matched case-control study was carried out analysing about 20 perinatal variables concerning mother and child. A total of 2757 infants who became diabetic during the period 19781988 were analysed. For each case infant three control children were randomly selected from among all infants born in the same year and at the same delivery unit as the case infant. The following statistically significant risk factors were identified for Type 1 diabetes with an onset before 15 years of age: maternal diabetes $(\mathrm{OR}=3.90)$, maternal age above 35 $(\mathrm{OR}=1.36)$, maternal non-smoking $(\mathrm{OR}=1.54)$, pre-eclamptic toxaemia $(\mathrm{OR}=1.19)$, caesarian section $(\mathrm{OR}=$ 1.32), and maternal-child blood group incompatibility $(\mathrm{OR}=1.61)$. When the analysis was restricted to Type 1 diabetes with an onset before the age of 5 years, most odds ratios were increased - for blood group incompatibility
$\mathrm{OR}=3.86$ (95\% confidence interval $1.54-9.65)$. Icterus without blood group incompatibility was not a significant risk factor. When each risk factor was analysed after standardization for all other risk factors, the odds ratios remained significantly increased. Scrutiny of medical records for cases and control children with a diagnosis of blood group incompatibility verified the diagnosis in close to $90 \%$ of children. The more severe cases needing phototherapy and/or blood transfusion were found to have a greater risk than milder cases. In conclusion, an early immunological event due to maternal-child blood group incompatibility, known to be associated with neonatal Beta-cell dysfunction, represents an increased risk for Type 1 diabetes in young children. Other stressful perinatal events may also be risk factors for Type 1 diabetes.

Key words. Perinatal risk factors, childhood Type 1 (insulindependent) diabetes mellitus, epidemiology, blood group incompatibility.
Type 1 (insulin-dependent) diabetes mellitus is thought to be the result of an immuno-pathogenic destruction of Beta cells [1]. From studies of identical twins [2] and from many population-based epidemiological studies [3], it is now clear that non-genetic risk factors play a major part in the aetiology of Type 1 diabetes. Such risk factors may be triggers of the immuno-pathogenic process many years before clinical onset of the disease as signs of autoim.munity appear early in the pre-diabetic stage [4-6]. Therefore, in the search for early triggers of Type 1 diabetes with clinical onset in childhood, it is interesting to study the fetal and perinatal periods of life. During fetal and perinatal life, the immune system is immature [7] and may therefore be vulnerable to immunological triggers, such as fetal infections or blood group incompatibility, and other stress factors. An example of such a mechanism may be the effect of rubella embryopathy: a very high frequency of diabetes $(20 \%)$ was found in children and young adults followed-up because of rubella embryopathy [8]. Exposure to nitrosamine compounds during fetal life as a result of a high intake of certain smoked food during pregnancy has also been suggested to increase the risk for Type 1 diabetes in children [9].

We report a case-control study on perinatal events and Type 1 diabetes, based on a linkage between two population-based health registries in Sweden: the Medical Birth Registry and a Childhood Diabetes Registry. All "exposure" information thus refers to data collected long before the onset of the disease and are therefore reasonably unbiased.

\section{Subjects and methods}

In Sweden, all children younger than 15 years with suspected diabetes are referred to paediatric departments. Those with a disease onset after June 1977 are reported to a central childhood 
Table 1. Maternal age as a risk factor for childhood Type 1 (insulindependent) diabetes

\begin{tabular}{|c|c|c|c|c|c|}
\hline \multirow[t]{2}{*}{$\begin{array}{l}\text { Maternal age } \\
\text { (years) }\end{array}$} & \multicolumn{2}{|c|}{$\begin{array}{l}\text { Type } 1 \text { diabetic } \\
\text { case children }\end{array}$} & \multicolumn{2}{|l|}{$\begin{array}{l}\text { Control } \\
\text { children }\end{array}$} & \multirow{2}{*}{$\begin{array}{l}\text { Odds ratio } \\
\text { in each stra- } \\
\text { tum }\end{array}$} \\
\hline & Number & $\%$ & Number & $\%$ & \\
\hline $15-19$ & 146 & 5.3 & 516 & 6.2 & 0.85 \\
\hline $20-24$ & 751 & 27.2 & 2412 & 29.2 & 0.93 \\
\hline $25-29$ & 1022 & 37.1 & 3115 & 37.5 & 0.99 \\
\hline $30-34$ & 594 & 21.5 & 1661 & 20.1 & 1.07 \\
\hline $35-39$ & 208 & 7.5 & 487 & 6.0 & 1.26 \\
\hline $40-44$ & 35 & 1.3 & 77 & 1.0 & 1.33 \\
\hline $45-49$ & 1 & 0.0 & 3 & 0.0 & 1.00 \\
\hline
\end{tabular}

diabetes registry [10]. This practice has been evaluated by both internal and external sources and shown to have an ascertainment level of at least 99\% [11]. From 1978-1988 a total of 2815 Type 1 diabetic children born during the period 1973-1987 were recorded in the diabetes registry.

The Medical Birth Registry run by the Swedish National Board of Health started in 1973 and collects data on the pregnancy, delivery and neonatal period for nearly all infants in Sweden [12]. Linkage between the two registries was performed using the unique personal identification number given to each Swedish citizen. Linkage was obtained for 2757 infants - there are different reasons for the lack of linkage for 51 ( $2 \%$ ) children. (1) The Type 1 diabetic child may have been born outside Sweden. (2) An error in the number used for linkage may exist in either registry. (3) Each year a few infants are never reported to the Medical Birth Registry. Forty-five of the Type 1 diabetic $(1.6 \%)$ and 123 of the control children ( $0.5 \%)$ were twins.

For each Type 1 diabetic child three control children were randomly selected from among all infants born during the same year and at the same delivery unit. Control children were accepted only if they were alive at the age at which the Type 1 diabetic child was diagnosed. The following variables recorded in the Medical Birth Registry at the time of the birth of the Type 1 diabetic and control children (thus prospectively with respect to Type 1 diabetes development) were analysed: maternal age, marital status (i.e. single parent or not), parity, diagnoses during pregnancy, work outside home during pregnancy (full or part-time work), smoking habits in early pregnancy (yes or no), maternal weight gain during pregnancy, mode of delivery, analgesia during delivery, operation anaesthesia, pregnancy duration, birth weight, length at birth, Apgar score, neonatal resuscitation, neonatal diagnoses (including maternal-child blood group incompatibility). Information on smoking habits and on maternal work were only available from 1982 onwards. Thus, this information was available for 306 diabetic and 916 control children. The validity of these variables has been evaluated [12] and shown to vary but should be similar between Type 1 diabetic and control children in the present study.

More detailed information concerning maternal-child blood group incompatibility and treatments given was obtained from studies of medical records for Type 1 diabetic and control children with the registry diagnosis. Among 24 Type 1 diabetic and 45 control children, medical records could be obtained for 21 and 40 children $(88 \%)$ respectively. A nested case-control study (i. e. a case-control study within the group of children who had all a diagnosis of maternal-child blood group incompatibility) was carried out using this material.

\section{Statistical analysis}

Relative risks were calculated using Mantel-Haenszel's estimates of an odds ratio for matched analyses. The $95 \%$ confidence intervals (CI) were estimated using the test-based method. The odds ratio is the ratio of cases and controls among exposed vs unexposed individuals and is equal to the relative risk in the case of low prevalent diseases, such as Type 1 diabetes. To standardize for confounders stratifications were made after breaking the matching. After stratification, the odds ratios were weighted according to Mantel-Haenszel's method [13]. Due to low numbers in the nested case-control study, conditional maximum likelihood estimates of odds ratios were determined, and exact mid- $p$ corrected $95 \%$ confidence intervals were determined using the StatXact program (CYTEL Software Corp, Cambridge, Mass., USA). Trends in frequency tables were tested using Armitage's technique [14].

\section{Results \\ Age at onset}

Onset of diabetes before the age of 5 years occurred in 906 of the Type 1 diabetic children, between 5 and 9 years of age in 1138 children, and between 10 and 14 years in 671 children. In two children, the age at onset of diabetes was not known.

\section{Maternal age}

Table 1 shows maternal age distribution in Type 1 diabetic and control children. There is a significant trend in odds ratio for Type 1 diabetes with increasing maternal age $\left(\chi^{2}\right.$ for trend $=16.5, p<0.001$ ). In the following analysis, maternal age 35 years and older is used as a risk factor.

\section{Gestational duration and birth weight}

Of the group $11 \%$ of the Type 1 diabetic and $10 \%$ of the control children were born before week 38 of gestation. Short gestational duration is a weak but significant risk factor for Type 1 diabetes (Table 2). Mean birth weight and body length for each week of gestational age do not differ between Type 1 diabetic and control children (data not shown).

\section{Risk factors for Type 1 diabetes by age at onset}

Table 2 shows some variables where odds ratios are found to be statistically significant. As it is conceivable that perinatal risk factors can have different effects on Type 1 diabetes of different age at onset, the data are shown for three subgroups according to age at onset: $0-4,5-9$, and $10-14$ years.

Crude odds ratios are presented based on MantelHaenszel analyses of quadruplets (Type 1 diabetic and three control children) and as odds ratios standardized for all other listed risk factors using the Mantel-Haenszel technique. This procedure only slightly affected the recorded odds ratios. After standardization, the effect of gestational age disappeared at an age of onset of 0 4 years, however, and should be considered an effect of associated phenomena.

A number of analysed variables did not differ between Type 1 diabetic and control children (data not shown): marital status of the mother, work outside home, maternal parity, low Apgar score (less than 6 at 5 min), frequency of resuscitation, maternal weight gain during pregnancy, single umbilical artery. 
Table 2. Perinatal risk determinants of onset of childhood Type 1 (insulin-dependent) diabetes in different age groups (twins and two case children with unknown age of onset excluded)

\begin{tabular}{|c|c|c|c|c|c|}
\hline \multirow[t]{2}{*}{ Variable } & \multirow[t]{2}{*}{ Age at onset (years) } & \multicolumn{2}{|c|}{ Number of infants } & \multirow[t]{2}{*}{ Crude OR $(95 \%$ CI $)$} & \multirow[t]{2}{*}{ Standardized OR $(95 \% \mathrm{CI})$} \\
\hline & & Cases & Controls & & \\
\hline \multirow[t]{4}{*}{$\begin{array}{l}\text { Maternal age } \\
\text { ( } \geq 35 \text { years) }\end{array}$} & $0-4$ & 95 & 227 & $\begin{array}{l}1.29 \\
(1.00-1.66)\end{array}$ & $\begin{array}{l}1.36 \\
(1.29-1.47)\end{array}$ \\
\hline & $5-9$ & 101 & 199 & $\begin{array}{l}1.61 \\
(1.25-2.08)\end{array}$ & $\begin{array}{l}1.58 \\
(1.48-1.70)\end{array}$ \\
\hline & $10-14$ & 35 & 100 & $\begin{array}{l}1.05 \\
(0.72-1.54)\end{array}$ & $\begin{array}{l}1.01 \\
(0.85-1.20)\end{array}$ \\
\hline & Total & 231 & 526 & $\begin{array}{l}1.36 \\
(1.15-1.59)\end{array}$ & $\begin{array}{l}1.37 \\
(1.32-1.41)\end{array}$ \\
\hline \multirow[t]{4}{*}{$\begin{array}{l}\text { Maternal } \\
\text { diabetes }\end{array}$} & $0-4$ & 22 & 16 & $\begin{array}{l}5.00 \\
(2.45-10.21)\end{array}$ & $\begin{array}{l}3.14 \\
(1.93-5.10)\end{array}$ \\
\hline & $5-9$ & 13 & 18 & $\begin{array}{l}2.60 \\
(1.27-5.32)\end{array}$ & $\begin{array}{l}1.86 \\
(1.01-3.43)\end{array}$ \\
\hline & $10-14$ & 11 & 7 & $\begin{array}{l}6.00 \\
(2.09-17.21)\end{array}$ & $\begin{array}{l}4.42 \\
(1.48-13.22)\end{array}$ \\
\hline & Total & 46 & 41 & $\begin{array}{l}3.90 \\
(2.48-6.12)\end{array}$ & $\begin{array}{l}2.95 \\
(2.40-3.64)\end{array}$ \\
\hline \multirow[t]{4}{*}{$\begin{array}{l}\text { Maternal } \\
\text { toxicosis }\end{array}$} & $0-4$ & 29 & 60 & $\begin{array}{l}1.47 \\
(0.94-2.28)\end{array}$ & $\begin{array}{l}1.28 \\
(1.02-1.60)\end{array}$ \\
\hline & $5-9$ & 29 & 59 & $\begin{array}{l}1.47 \\
(0.95-2.29)\end{array}$ & $\begin{array}{l}1.48 \\
(1.13-1.78)\end{array}$ \\
\hline & $10-14$ & 10 & 35 & $\begin{array}{l}0.85 \\
(0.42-1.75)\end{array}$ & $\begin{array}{l}0.77 \\
(0.45-1.31)\end{array}$ \\
\hline & Total & 68 & 154 & $\begin{array}{l}1.33 \\
(1.00-1.77)\end{array}$ & $\begin{array}{l}1.23 \\
(1.12-1.34)\end{array}$ \\
\hline \multirow[t]{3}{*}{$\begin{array}{l}\text { Maternal } \\
\text { non-smoking }\end{array}$} & $0-4$ & 205 & 572 & $\begin{array}{l}1.33 \\
(0.94-1.89)\end{array}$ & $\begin{array}{l}1.30 \\
(1.16-1.45)\end{array}$ \\
\hline & $5-9$ & 36 & 6 & $\begin{array}{l}4.18 \\
(1.55-11.25)\end{array}$ & $\begin{array}{l}4.55 \\
(2.17-10.00)\end{array}$ \\
\hline & Total & 241 & 578 & $\begin{array}{l}1.54 \\
(1.11-2.14)\end{array}$ & $\begin{array}{l}1.52 \\
(1.39-1.67)\end{array}$ \\
\hline \multirow[t]{4}{*}{$\begin{array}{l}\text { Gestational age } \\
(<38 \text { weeks) }\end{array}$} & $0-4$ & 35 & 100 & $\begin{array}{l}1.39 \\
(1.05-1.83)\end{array}$ & $\begin{array}{l}0.93 \\
(0.77-1.11)\end{array}$ \\
\hline & $5-9$ & 58 & 156 & $\begin{array}{l}1.13 \\
(0.90-1.41)\end{array}$ & $\begin{array}{l}1.04 \\
(0.93-1.15)\end{array}$ \\
\hline & $10-14$ & 40 & 92 & $\begin{array}{l}1.12 \\
(0.82-1.53)\end{array}$ & $\begin{array}{l}1.24 \\
(1.05-1.47)\end{array}$ \\
\hline & Total & 133 & 348 & $\begin{array}{l}1.19 \\
(1.03-1.139)\end{array}$ & $\begin{array}{l}1.07 \\
(1.02-2.12)\end{array}$ \\
\hline \multirow[t]{4}{*}{$\begin{array}{l}\text { Caesarian } \\
\text { section }\end{array}$} & $0-4$ & 113 & 252 & $\begin{array}{l}1.40 \\
(1.11-1.78)\end{array}$ & $\begin{array}{l}1.25 \\
(1.17-1.34)\end{array}$ \\
\hline & $5-9$ & 130 & 292 & $\begin{array}{l}1.39 \\
(1.11-1.73)\end{array}$ & $\begin{array}{l}1.27 \\
(1.20-1.34)\end{array}$ \\
\hline & $10-14$ & 50 & 143 & $\begin{array}{l}1.05 \\
(0.76-1.45)\end{array}$ & $\begin{array}{l}0.91 \\
(0.79-1.03)\end{array}$ \\
\hline & Total & 293 & 687 & $\begin{array}{l}1.32 \\
(1.14-1.52)\end{array}$ & $\begin{array}{l}1.20 \\
(1.17-1.23)\end{array}$ \\
\hline \multirow{4}{*}{$\begin{array}{l}\text { Neonatal } \\
\text { respiratory } \\
\text { disease }\end{array}$} & $0-4$ & 52 & 120 & $\begin{array}{l}1.33 \\
(0.95-1.87)\end{array}$ & $\begin{array}{l}1.20 \\
(1.04-1.37)\end{array}$ \\
\hline & $5-9$ & 67 & 193 & $\begin{array}{l}1.05 \\
(0.78-1.41)\end{array}$ & $\begin{array}{l}1.00 \\
(0.91-1.09)\end{array}$ \\
\hline & $10-14$ & 35 & 96 & $\begin{array}{l}1.10 \\
(0.73-1.66)\end{array}$ & $\begin{array}{l}1.03 \\
(0.86-1.24)\end{array}$ \\
\hline & Total & 154 & 409 & $\begin{array}{l}1.14 \\
(0.94-1.39)\end{array}$ & $\begin{array}{l}1.06 \\
(1.01-1.10)\end{array}$ \\
\hline \multirow[t]{4}{*}{$\begin{array}{l}\text { Blood group } \\
\text { incompatibility }\end{array}$} & $0-4$ & 9 & 7 & $\begin{array}{l}3.86 \\
(1.54-9.65)\end{array}$ & $\begin{array}{l}4.13 \\
(1.40-12.19)\end{array}$ \\
\hline & $5-9$ & 10 & 20 & $\begin{array}{l}1.50 \\
(0.71-3.19)\end{array}$ & $\begin{array}{l}1.24 \\
(0.62-2.50)\end{array}$ \\
\hline & $10-14$ & 5 & 18 & $\begin{array}{l}0.82 \\
(0.29-2.33)\end{array}$ & $\begin{array}{l}0.83 \\
(0.31-2.18)\end{array}$ \\
\hline & Total & 24 & 45 & $\begin{array}{l}1.61 \\
(0.98-2.65)\end{array}$ & $\begin{array}{l}1.57 \\
(1.18-2.08)\end{array}$ \\
\hline
\end{tabular}


Table 3. Results of study of medical records for Type 1 (insulin-dependent) diabetic and control children with a diagnosis of maternal- child blood group incompatibility in the registry

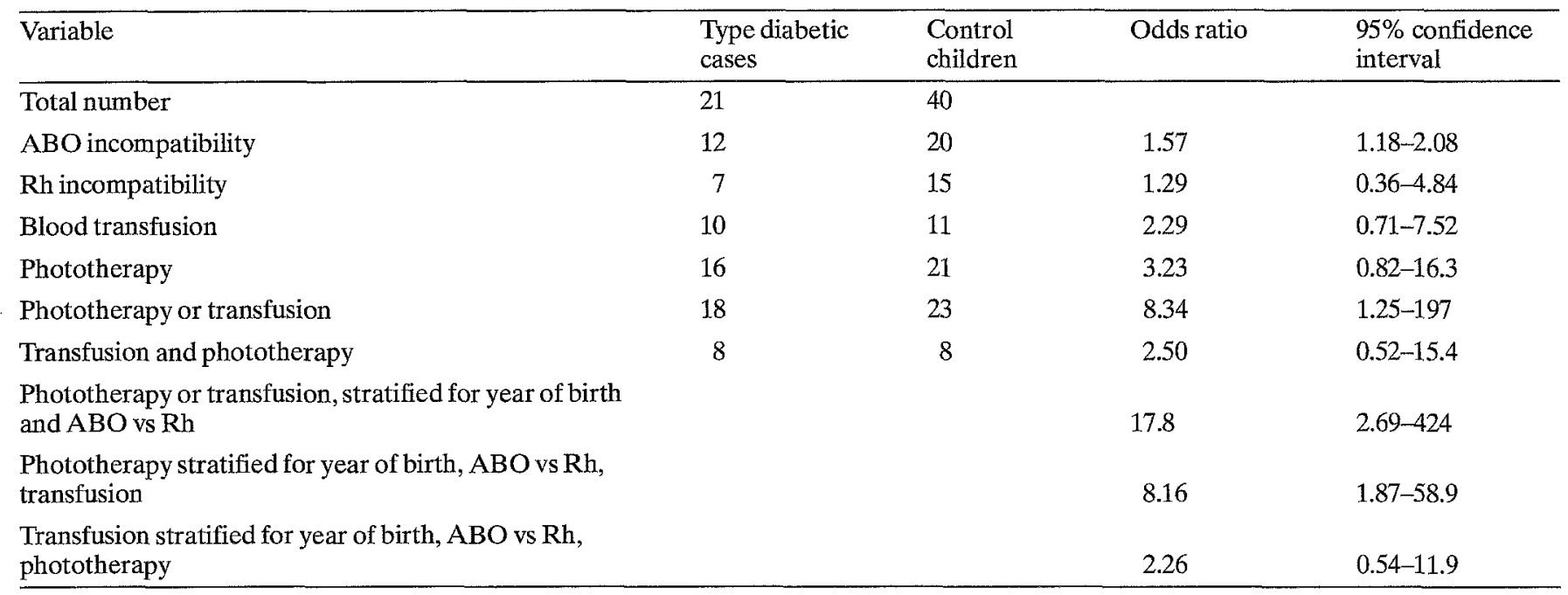

Among the odds ratios listed in Table 2, the majority are below 2 but two odds ratios are high: maternal diabetes (2.95) and maternal-child blood group incompatibility for an age of onset of Type 1 diabetes below 5 years (4.13). The odds ratio for icterus without blood group incompatibility was 1.14 (0.93-1.40).

\section{Nested case-control study on children with diagnosis of blood group incompatibility}

Sixty-one medical records were retrieved $(88 \%)-21$ Type 1 diabetic and 40 control children. The records were studied by one of us (GD) without knowledge of the case/control status of the child. The following items were recorded: $\mathrm{Rh}, \mathrm{ABO}$ immunization or not (wrongly classified); blood transfusion performed or not; phototherapy performed or not (Table 3). In one control child, it was not clear whether therapy had been given.

The diagnosis of blood group incompatibility was verified based on medical recording of maternal-child blood groups, icterus and Coombs testing in $90 \%$ of Type 1 diabetic and $88 \%$ of control children (no significant difference).

Both phototherapy and blood transfusion were associated with an increased odds ratio but neither reached statistical significance. Any treatment (phototherapy or transfusion or both) was associated with a high odds ratio which reached statistical significance. At an age of diabetes onset before 5 years, seven of eight Type 1 diabetic and all six control children had received treatment, while at an age of onset of 5 years or more, all case children and only 17 of 28 control children had received treatment. This difference may be random, however, the exact Zelen test [15] gives $p=0.17$. As therapeutic traditions have changed with time towards more frequent use of phototherapy, the data were stratified also for year of birth (in 3-year periods). The increase in risk for any treatment was then augmented as was transfusion vs no transfusion and phototherapy vs no phototherapy. The latter then became clearly significant (Table 3 ).

\section{Discussion}

In a previous case-control study comprising 339 Type 1 diabetic and 528 control children, among other exposures, perinatal events were also recorded but not identified as risk factors for Type 1 diabetes [16]. As the frequency of such events are very low in Sweden, the power of that study in this respect was low and it was pointed out that a much larger study was necessary to answer the question whether perinatal events that could affect the neonatal immune system might be risk factors for Type 1 diabetes.

In the present study we have identified a set of perinatal events, which seem to be associated with an increased risk of developing Type 1 diabetes in childhood. The conclusions are mainly based on data from the Medical Birth Registry, the precision of some of which may be low [12] but similar for Type 1 diabetic and control children and could therefore only lead to a bias towards unity of the odds ratios. Most of the identified risk factors represent stressful perinatal events, such as pre-eclamptic toxaemia of pregnancy, low gestational age, caesarian section, neonatal respiratory disease, the odds ratios for which are low. The finding of a significant trend in the increase of the odds ratio for Type 1 diabetes with increasing maternal age strongly suggests a true association and is in agreement with other studies $[16,17]$. The increase in risk is still significant after standardization for the other significant risk factors found in this study and thus other risk factors associated with old maternal age, e.g. pregnancy and delivery differences not recorded in our study, may explain the increased odds ratio.

Except for maternal diabetes (when obviously a genetic factor can play an important role), the strongest elevated odds ratio was seen for maternal-child blood group incompatibility (the highest odds ratio was 4.13 , at an age of onset below 5 years). It is not explainable by the icterus, because icterus without blood group incompatibility was not associated with a significantly increased risk. When maternal-child blood group incompatibility was 
present, ABO immunization seemed to be a slightly greater risk factor than $\mathrm{Rh}$ immunization, but the difference was not statistically significant. Treatment with phototherapy or blood transfusion represented an increased risk. There was an increase in odds ratio for both transfusion and phototherapy, which was slightly higher for phototherapy, but the association did not reach statistical significance for either treatment, neither was there an indication of synergism between the two. As both treatments were given in many cases and as the therapeutic traditions have changed with time, we standardized each therapy for each other and for the year of birth. The odds ratio for treatment or not was then even more pronounced and phototherapy was associated with a significant increase in risk whereas the increase in risk for transfusion was still statistically non-significant. These results may be an expression of the fact that the more severe cases are treated more often than are the mild cases. Whether phototherapy per se might be a risk factor for Type 1 diabetes cannot be excluded in this study, but the fact that children with the diagnosis of icterus without blood group incompatibility had no increase in risk for the disease argues against this.

The present study gives no clue as to the mechanism behind the finding of blood group incompatibility as a risk factor for early-onset Type 1 diabetes but this early immunological event might well be causally related to Type 1 diabetes as there is clear evidence of Beta-cell dysfunction with hyperinsulinaemia, hyperplasia of the islets of Langerhans and hypoglycaemia in newborns with moderate to severe erythroblastosis fetalis [18]. Hypothetically, this early immunological event could unspecifically affect the fetal immune system and induce intolerance to Beta-cell autoantigens. A more specific effect with an early Betacell damage induced by the circulating immune complexes associated with the blood group incompatibility may be another possibility.

Surprisingly, maternal non-smoking was associated with an increased risk of developing childhood Type 1 diabetes. As it has previously been shown that preeclamptic toxaemia is more prevalent among non-smoking mothers [19] and as pre-eclamptic toxaemia also appeared as a risk factor for Type 1 diabetes, the association between the two may yield an explanation. Though still under debate, there is evidence that pre-eclamptic toxaemia is an immunological disease [7]. Thus, an early immunological disturbance of the child may be a trigger for later development of Type 1 diabetes. It is true that the effect of non-smoking remained after stratification for toxaemia - and vice versa -, but the registration of toxaemia is variable and certainly not complete.

It is concluded that perinatal events are related to an increased risk for childhood Type 1 diabetes. Some of the risk factors may act through unspecific perinatal stress or through confounding factors not yet identified. The striking effect of maternal-child blood group incompatibility, known to be associated with neonatal Beta-cell dysfunction, may act as an immunological trigger and the association should be further explored.
Acknowledgements. This study was supported by grants from the Swedish Medical Research Council, project No.07531, the Karolinska Institute, and the Swedish Diabetes Association. Help in preparing record linkage was obtained by Mr. A. Ericson and Mr. J. Gunnarskog, National Board of Health, Sweden.

\section{References}

1. Nerup J, Lernmark $\AA$ (1981) Autoimmunity in insulin-dependent diabetes mellitus. Am J Med 70: 135-141

2. Barnett AH, Eff C, Leslie DG, Pyke DA (1981) Diabetes in identical twins. A study of 200 pairs. Diabetologia 20: 87-93

3. Dahlquist $\mathbf{G}$ (1991) Epidemiological studies of childhood insulin-dependent diabetes. Acta Paediatr Scand 80: 583-588

4. Bottazzo GF, Dean BM, Gorsuch AN, Cudworth $\mathrm{AG}_{2}$, Doniack D (1980) Complement-fixing islet-cell antibodies in type 1 diabetes: possible monitors of active $\beta$-cell damage. Lancet $\mathrm{I}$ : 668-672

5. Gorsuch AN, Spencer KM, Lister J et al. (1981) Evidence for a long prediabetic period in type 1 (insulin-dependent) diabetes mellitus. Lancet II: 1363-1365

6. Srikanta S, Ganda OP, Eisenbarth GS, Soeldner JS (1983) Isletcell antibodies and $\beta$-cell function in monozygotic triplets and twins initially discordant for type 1 diabetes mellitus. N Engl J Med 308: 322-325

7. Soothill JF, Hayward AR, Woods CBS (1983) Paediatric immunology. Blackwell, Oxford

8. Menser MA, Forrest JM, Bransby RD (1978) Rubella infection and diabetes mellitus. Lancet I: 57-60

9. Helgasson T, Jonasson MR (1981) Evidence for a food additive as cause of ketone-prone diabetes. Lancet II: 716-720

10. Dahlquist G, Gustavsson KH, Holmgren G et al. (1982) The incidence of diabetes mellitus in children 0-14 years of age. A prospective study 1977-80. Acta Paediatr Scand 71:7-14

11. Nyström L, Dahlquist G, Rewers M, Wall S (1990) The Swedish Childhood Diabetes Study. An analysis of the temporal variation in diabetes incidence 1978-1987. Int J Epidemiol 19: 141-146

12. Cnattingius S, Ericson A, Gunnarskog J, Källén B (1990) A quality study of a medical birth registry. Scand J Soc Med 18: 143148

13. Mantel N, Haenszel W (1959) Statistical aspects of the analysis of data from retrospective studies of disease. J Natl Cancer Inst 32: $719-748$

14. Armitage $P(1955)$ Tests for linear trends in proportions and frequencies. Biometrics 11:375-386

15. Zelen M (1971) The analysis of several $2 \times 2$ contingency tables. Biometrika 58: 129-137

16. Blom L, Dahlquist G, Nyström L, Sandström A, Wall S (1989) The Swedish Childhood Diabetes Study - Social and perinatal determinants for diabetes in childhood. Diabetologia 32: 7-13

17. Wagener DK, La Porte RE, Orchard TJ, Cavender D, Kuller LH, Drash AL (1983) The Pittsburgh study of insulin-dependent diabetes mellitus. Risk of diabetes among relatives. Diabetologia 25: $82-88$

18. Aynsley-Green A, Soltész G (1985) Neonatal hypoglycemia. In: Aynsley-Green A, Soltész G (eds) Hypoglycemia in infancy and childhood. Churchill Livingstone, Edinburgh, p 58

19. Duftus G, MacGilliway I (1968) The incidence of preeclamptic toxaemia in smokers and non-smokers. Lancet I: $994-998$

Received: 4 December 1991

and in revised form: 20 March 1992

Dr. G. Dahlquist

Department of Pediatrics

Umeå University Hospital

S-901 85 Umeå

Sweden 